\title{
EFFECTS OF THE INCORPORATION OF TRITIATED ADENOSINE INTO MOUSE OVARIES ON OVULATION AND DEVELOPMENTAL CAPACITY OF OVA
}

\author{
ROSEMARY BACHVAROVA \\ Department of Anatomy, Cornell University Medical College, New York, \\ N.Y. 10021, U.S.A.
}

(Received 12th February 1974)

The sensitivity of mammalian oocytes to irradiation has been recently summarized (Baker, 1971). This report describes the effects of $\beta$-radiation from $\left[8-{ }^{3} \mathrm{H}\right]$ adenosine incorporated into the ovary, on ovulation and on the developmental capacity of ovulated ova.

Female ICR mice which were 24 to 26 days old and had been reared in our colony were used in all experiments. Ovaries were exposed to $\left[8-{ }^{3} \mathrm{H}\right]$ adenosine by injecting $5 \mu \mathrm{l}$ of a concentrated solution into the ovarian bursa. The precursor solution contained 12.5 to $50 \mu \mathrm{Ci}$ (Schwarz-Mann, 15 to $25 \mathrm{mCi}$ / $\mu \mathrm{mol})$ in $5 \mu \mathrm{l}$ sterile mammalian Ringer's solution buffered at $\mathrm{pH} 7$ with $2 \mathrm{~mm}$-phosphate. Using $25 \mu \mathrm{Ci}$ per ovary, the total uptake into the ovary reaches a peak of $7 \%$ of the injected precursor in $2 \mathrm{hr}$, and total incorporation into the nucleic acid fraction of the ovary reaches a peak of $2 \%$ in 1 to 2 days ( $R$. Bachvarova, in preparation).

The effect of exposure of the ovary to $\left[8-{ }^{3} \mathrm{H}\right]$ adenosine on the number of ova released by superovulation is shown in Text-fig. 1. Superovulation was induced by intraperitoneal injection of 7.5 i.u. PMSG (Gestyl, Organon) followed $48 \mathrm{hr}$ later by an intraperitoneal injection of 7.5 i.u. HCG (Pregnyl, Organon). Ova were collected and counted from 1 to 26 days after bursal injection of the radioactive precursor, and $90 \%$ of the ova were judged to be normal. As can be seen from Text-fig. 1, the yield of ova per female after bursal injection of $50 \mu \mathrm{Ci}\left[8-{ }^{3} \mathrm{H}\right]$ adenosine per ovary increased for ovulations within 1 and 2 days, declined by almost $50 \%$ from the initial value within 12 days, remained approximately constant up to 21 days, and declined further after 21 days. The decrease in ovulation was less pronounced when the amount of $\left[8-{ }^{3} \mathrm{H}\right]-$ adenosine injected was reduced.

The increased yield of ova at 1 and 2 days after exposure to the tritiated precursor appears to be analogous to the superovulation observed shortly after X-irradiation (Russell \& Russell, 1956).

Since the range of the low energy $\beta$-rays from tritium decay is short (mean range in biological material is $0.6 \mu \mathrm{m}$; Feinendegen, 1967), most of the radiation received by the oocyte must be due to uptake of the labelled precursor into the oocyte itself. Oocytes may be entirely absent from the ovaries of sexually 
mature mice due to radiation from $\left[{ }^{3} \mathrm{H}\right]$ thymidine incorporated into the oocytes in embryonic life (Baker \& McLaren, 1973). The decreased yield of ova seen at 7 days or more after exposure to $\left[8-{ }^{3} \mathrm{H}\right]$ adenosine may be correlated with the observation that growing oocytes and primordial oocytes actively incorporate labelled RNA precursors into RNA, while fully grown oocytes, known to be within 5 days of ovulation (Pedersen, 1970), do not (Baker, Beaumont \& Franchi, 1969; R. Bachvarova, in preparation). However, oocytes within 5 days of ovulation do take up the precursor into the acid-soluble fraction (R. Bachvarova, in preparation) and presumably receive radiation from this

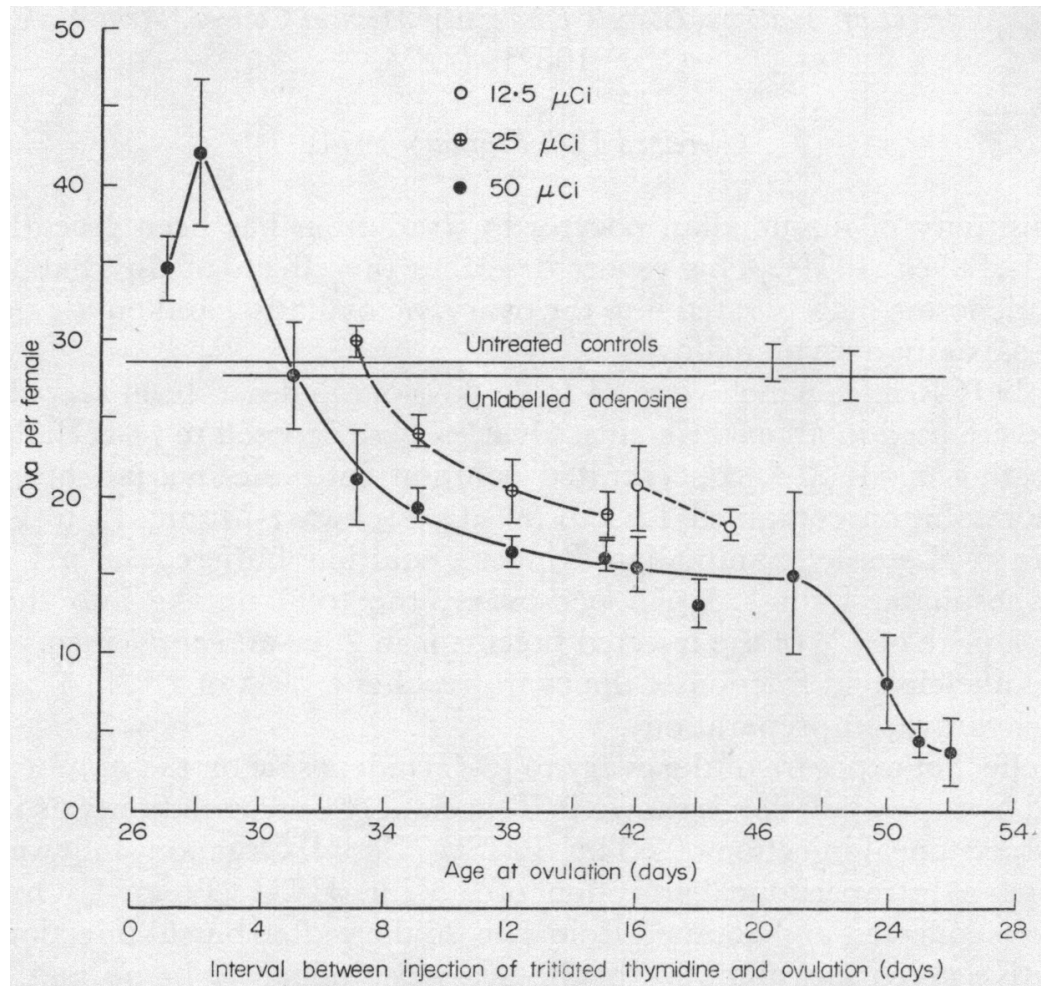

TEXr-Fig. 1. The number of ova superovulated at intervals after bursal injection of various amounts $(\mu \mathrm{Ci})$ of $\left[8-{ }^{3} \mathrm{H}\right]$ adenosine. The vertical bars indicate the mean \pm S.E.M. for each point. For the untreated controls, the yield of ova was averaged from 125 mice in which ovulation occurred at 26 to 50 days of age. Fifty mice received bursal injection of $0.0025 \mu \mathrm{mol}$ of unlabelled adenosine, the same amount of adenosine as is contained in $50 \mu \mathrm{Ci}$ of $\left[8-{ }^{3} \mathrm{H}\right]$ adenosine, specific activity $20 \mathrm{mCi} / \mu \mathrm{mol}$, and were subjected to superovulation 16 to 25 days later.

source. The relative dose delivered to growing versus fully grown oocytes is difficult to compute and the relative sensitivity of these two classes of oocytes is unknown (Baker, 1971). The further decrease in ovulation seen after 21 days may be due to elimination of primordial oocytes. In the mouse, these are known to require more than 19 days to reach ovulation (Pedersen, 1970), and to be much more radiosensitive than growing oocytes (Baker, 1971). In considering the relative dose received by primordial oocytes versus growing oocytes, it is 
known only that less labelled RNA is retained to ovulation by primordial oocytes than by growing oocytes ( $R$. Bachvarova in preparation).

In addition to a direct effect of incorporated $\left[8-{ }^{3} \mathrm{H}\right]$ adenosine on the oocytes, it is possible that damaged follicular cells may play a rôle in the decrease in ovulation. Follicular cells are dividing and incorporate $\left[8{ }^{3} \mathrm{H}\right]$ adenosine into DNA as well as RNA. They may therefore be expected to undergo considerable radiation damage.

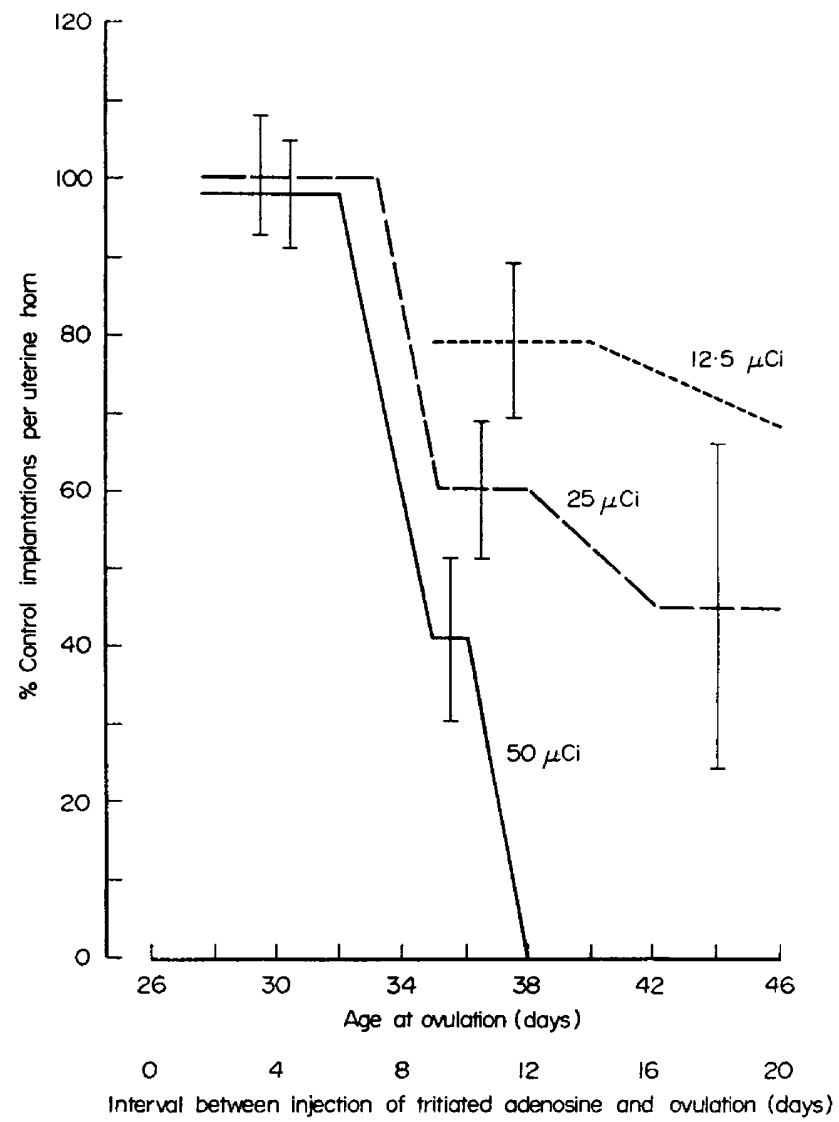

TEXT-FIG. 2. The effect of unilateral bursal injection of various amounts $(\mu \mathrm{Ci})$ of $\left[8_{-}{ }^{3} \mathrm{H}\right]-$ adenosine on ovulation and development of eggs from the affected ovary. The data from mice mating within 2 to 7 days were grouped and the mean \pm S.E.M. determined. Of the implantations derived from the treated ovary, $92 \%$ contained normal embryos. The total number of implantations per uterine horn in control mice $(7.3)$ was determined by averaging the number of implantations per uterine horn observed in sixty-seven untreated (age unknown) ICR mice dissected at Day 13 of pregnancy.

The number of ova ovulated after exposure of the ovary to $\left[8-{ }^{3} \mathrm{H}\right]$ adenosine was tested under a different set of conditions. Female mice (24 to 26 days old) received a unilateral bursal injection of a given amount of $\left[8-{ }^{3} \mathrm{H}\right]$ adenosine. The females were placed with fertile males at various subsequent times to permit normal (not superovulation-induced) mating. The females were killed 8 to 13 days after finding a vaginal plug, and the total numbers of implantation 
sites derived from both the radioactive and control ovaries were recorded. The number of implantations observed is plotted in Text-fig. 2 as the average percentage of total implantations found in one uterine horn of control untreated females. At a dose of $50 \mu \mathrm{Ci} /$ ovary, the number of implantations from the treated ovary was reduced from $98 \%$ to $0 \%$ of the control value in the period from 10 to 16 days after initial exposure to the precursor. The contralateral ovary increased its yield by $75 \%$ over the same period. The total number of implantations in both uterine horns of the experimental animals averaged 13.0, 89\% of the value for control mice. The phenomenon of compensatory ovulation, which functions to maintain normal litter size when one ovary is damaged or removed, is well known in rodents (Chatterjee \& Greenwald, 1972). Thus, the decrease in implantations derived from the labelled ovary is presumably due mainly to a decrease in ova ovulated with a compensatory increase in ova ovulated from the untreated ovary. The decline observed in Text-fig. 2 has a different time course from that shown in Text-fig. 1 since superovulation was not involved, and only one ovary was exposed to radiation.

In order to test the developmental capacity of ova released from ovaries exposed to $\left[8-{ }^{3} \mathrm{H}\right]$ adenosine, females received bilateral bursal injections of $\left[8-{ }^{3} \mathrm{H}\right]$ adenosine, were injected with PMSG and HCG to cause superovulation 11 to 19 days later, and mated to fertile males during the night following HCG injection. The females were killed 8 to 11 days later, and the numbers of implantation sites and of normal embryos were recorded. The percentage of the theoretical number of ova which resulted in an implantation site was:

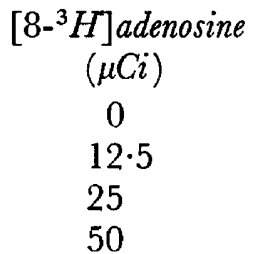

$\%$ Development
(Mean \pm S.E.)
$49 \pm 8$
$87 \pm 14$
$67 \pm 17$
$50 \pm 9$

The number of ova expected after superovulation was determined from the curves in Text-fig. 1. Of seventy-one experimental females injected with PMSG and HCG and exposed to males, only twenty-nine females which had implantation sites, demonstrating successful mating, were used for collection of the data; $66 \%$ of the implantation sites contained normal embryos. For the controls, the data were derived from eleven out of forty-one females aged 34 to 45 days which showed successful mating after superovulation; $68 \%$ of the implantation sites contained normal embryos. The \% development does not fall below that of the control untreated females. In those cases in which the level rises above that of the controls, the decreased ovulation indicated in Text-fig. 1 appears to be due to a preferential decrease in the release of eggs incapable of normal development.

In conclusion, the decrease in number of ova ovulated after exposure of mouse ovaries to tritiated adenosine is probably due to the radiation delivered to the oocyte from the precursor taken up and incorporated into RNA of the oocyte. These data correlate well with the known sensitivity of oocytes to radiation damage. The developmental capacity of the ova which are released is apparently not impaired. 
The author wishes to thank Mrs Nancy Chein for her technical assistance. This investigation was supported by grants GM-17921 and HD-06910 from the National Institutes of Health.

\section{REFERENCES}

BAKER, T. G. (1971) Comparative aspects of the effects of radiation during oogenesis. Mutation Res. $11,9$.

Baker, T. G., Beaumont, H. M. \& Franchi, L. L. (1969) The uptake of tritiated uridine and phenylalanine by the ovaries of rats and monkeys. F. Cell Sci. 4, 655 .

Baker, T. G. \& McLaren, A. (1973) The effect of tritiated thymidine on the developing oocytes of mice. 7. Reprod. Fert. 34, 121.

Ghatterjee, A. \& Greenwald, G. S. (1972) The long-term effects of unilateral ovariectomy of the cycling hamster or rat. Biol. Reprod. 7, 238.

Feinendegen, L. L. (1967) Tritium-Labeled Molecules in Biology and Medicine. Academic Press, New York.

Pedersen, T. (1970) Follicle kinetics in the ovary of the cyclic mouse. Acta endocr., Copenh. 64, 304.

Russell, L. B. \& Russell, W. L. (1956) The sensitivity of different stages in oogenesis to the radiation induction of dominant lethals and other changes in the mouse. In Progress in Radiobiology, p. 187. Eds. J. S. Mitchell, B. E. Holmes and C. L. Smith. C. C. Thomas, Springfield, Ill. 